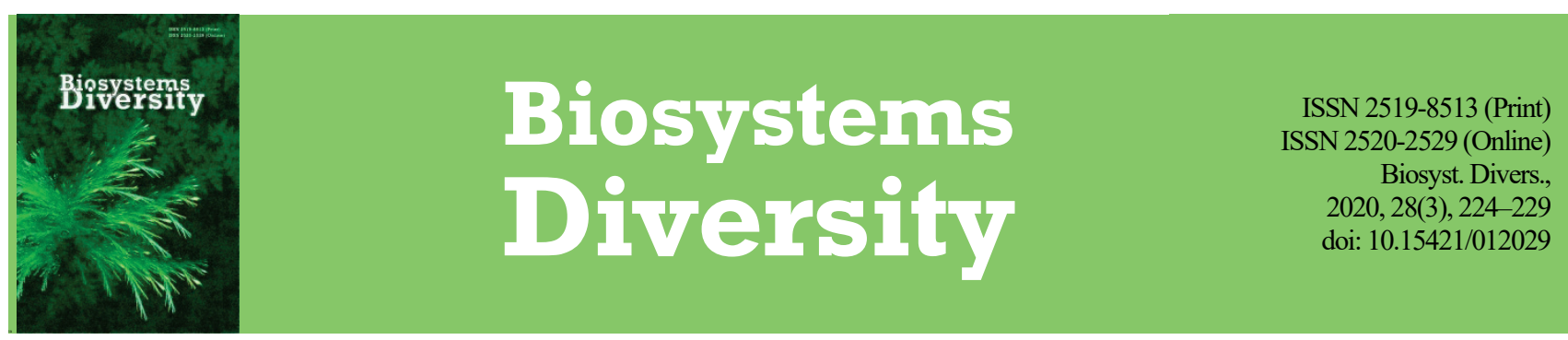

\title{
Dynamics of plant cover of meadow steppes after the cessation of traditional management in Opillia
}

\author{
I. I. Dmytrash-Vatseba*, N. V. Shumska** \\ *Halych National Nature Park, Halych, Ukraine \\ **Vasyl Stephanyk Precarpathian National University, Ivano-Frankivsk, Ukraine
}

Article info

Received 18.05.2020

Received in revised form 20062020

Accepted 23.06.2020

\author{
Dmytrash-Vatseba, I. I., \& Shumska, N. V. (2020). Dynamics of plant cover of meadow steppes after the cessation of traditional \\ management in Opillia. Biosystems Diversity, 28(3), 224-229. doi:10.15421/012029
}

Halych National Nature Park, Halych-hora st., 1, Halych, 77100, Ukraine. Tel.: +38-067-735-25-21 E-mail: iradmytrash@ukr.net

Vasyl Stephanyk

Precarpathian National University, Halytska st., 201B, Ivano-Frankivsk, 76000, Ukraine.

Tel.: + 38-097-562-48-23. E-mail:

shumskabotan@gmail.com

Meadow steppes of Opillia (western edge of Podillia Upland, Western Ukraine) belong to xerothermic calcareous grasslands which are the most species-rich habitats in Europe. This paper contains results of a nine-year study (2010-2018 years) of plant species composition in 'Ostrivets' grassland after the cessation of traditional management (mowing). The patch had been burnt for at least five years running and then abandoned for five more years. The patch was chosen as a model grassland of abandoned meadow steppes. We examined plant species richness and composition on three sample plots of $5 \times 5 \mathrm{~m}^{2}$. In 2010, at the beginning of annual burning practice the plots harboured 114 species. One year after cessation of disturbance by fire (2014), species richness decreased to 108 species. In 2018, after five years of abandonment it reached 83 species. Abundance of the dominant species (Brachypodium pinnatum) remained unchanged when the patch was under annual burning regime. After abandonment of the habitat Molinia arundinacea became the dominant species. Species composition experienced changed as well. Only $37.9 \%$ of species remained in the sample plots from 2010 till 2018. The proportion of meadow-steppe species halved, they were substituted by species of forests, forest edges and ruderal species. Percent of meadow species did not significantly change, however this group of species began to dominate within the community. The cover of woody vegetation reached $15-20 \%$ in 2018 . Rubus caesius encroached on the grassland in 2014 and gained $20 \%$ of projective cover in 2018. Ten out of thirteen rare species disappeared from the habitat during the study period. 'Ostrivets' habitat requires urgent measures to be taken to restore and preserve meadow-steppe species composition. We suggest the following measures: elimination of trees and shrubs, regular moving and overseeding of extinct species.

Keywords: meadow steppe; burning; abandonment; plant species richness; plant species composition; Opillia.

\section{Introduction}

Calcareous xerothermic grasslands, the most species rich habitats throughout Europe, are equally mostly threatened habitats (Poschlod \& Wallis De Vries, 2002; Wallis De Vries et al., 2002; Butaye et al., 2005). The majority of xerothermic calcareous grasslands originated as secondary vegetation after the clearing of forests, especially those on gentle slopes and hill plateaus. Extreme species richness has developed in sites with extreme conditions characterized by excess of light, soil moisture deficiency, low content of nutrients etc. (Gorban et al., 2020). Open shortgrass vegetation in these habitats has been maintained firstly by wild herbivores that were later replaced by domestic grazing animals. Occasional fire and mowing complemented the impact of grazing. Such management lasted until the mid-XX century when agricultural intensification and afforestation began (Dzwonko \& Loster, 1998). This land use resulted in fragmentation of natural landscape, reduction of habitat quality and decrease of species richness. As for xerothermic grasslands, the remaining ones were transformed into small and isolated patches, some of which were overgrazed, the others - abandoned.

Decrease in species richness is a well-known consequence of cessation of traditional management in extremely species rich European xerothermic calcareous grasslands (Hansson \& Fogelfors, 2000; Poschlod et al., 2005; Provoost et al., 2004; Pykälä et al., 2005; Römermann et al., 2009; Stoate et al., 2009; When et al., 2017). Succession following abandonment of dry grasslands begins with increasing litter deposition, changes in soil nutrient availability, especially nitrogen, reduction of light availability, suppression of low-growing vegetation by tall expansive plants, encroachment of woody species etc. (Butaye et al., 2005; Dostálek \& Frantík, 2008). The small area of patches and isolation of habitats, as well as pesticide spillover from surrounding arable lands additionally accelerate deterioration of habitat quality (Krauss et al., 2004; Zulka et al., 2014). Xerothermic grasslands in Opillia physiographic region (situated on the western edge of Podillia Upland, Western Ukraine) also exist in such unfavourable conditions. Opillia is highly transformed by humans and belongs to most ancient agricultural regions of Ukraine. Arable lands take up over 75 percent of its area. Consequently, remnants of natural and semi-natural vegetation are fragmented, isolated and altered by humans. Xerothermic calcareous grasslands are simultaneously among the most species-rich and transformed habitats in Opillia. Meadow steppes are extra-zonal vegetation here, as Opillia belongs to the deciduous forest zone (Rudenko, 2008). Meadow steppes have been established here at southern slopes of hills under grazing or mowing regime. Well preserved xerothermic grasslands currently occupy nearly $0.6 \%$ of the area; however, the habitat quality is rapidly deteriorating. In the last few years due to decrease of livestock number, plant species composition of the grasslands has been changing, they have been overgrown with thermophilous shrubs and trees. Gentle slopes and plateaus of hills are the most susceptible places for invasive species colonization.

Vegetation cover of meadow steppes of Opillia has been partially studied, the majority of papers focused on vegetation and rare species of xerothermic grasslands (Kukovitsia, 1976; Sheliag-Sosonko et al., 1981; Kukovitsia et al., 1994; Kukovitsia et al., 1998; Dmytrash-Vatseba, 2016, 2017; Zamoroka et al., 2018; Roleček et al., 2019). Transformation of plant cover of meadow steppes in Opillia caused by cessation of traditional land use remained unclear.

'Ostrivets' grassland was chosen for our study as it generally describes characteristic conditions of existence of meadow steppes in Opillia. The patch has been fragmented, the remaining part is up to 2 ha and is 
completely isolated. Agricultural lands surround the habitat on all sides. Plant cover of the grassland had been under different types of anthropogenic impact (mowing, early spring burning). Since disturbances had ceased, vegetation of the habitat began transforming. Besides its small area and isolation, at the beginning of our study the patch harboured a high species richness common to meadow steppes of Opillia. We have found a range of rare species of plants there.

In this paper we aimed to show changes in floristic composition and species abundance of the xerothermic grassland 'Ostrivets' at the beginning of annual burning, after several years of disturbance by fire and after five years of abandonment.

\section{Material and Methods}

'Ostrivets' xerothermic grassland situated near Medukha village of Halych district of Ivano-Frankivsk region was chosen as the model patch of meadow steppes. Geographic coordinates were as follows: $49^{\circ} 09^{\prime} 58^{\prime \prime} \mathrm{N}$ $24^{\circ} 50^{\prime} 00^{\prime \prime} \mathrm{E}$, the total area of the patch was 2 ha. The meadow steppe has formed at the flat top of the hill ( $330 \mathrm{~m}$ a.s.l.) with a karst sink hole in its central part, that is overgrown by shrubs and young trees. The patch of rectangular shape is surrounded on all sides by plowed fields that had not been cultivated for eighteen years. However, these lands have been sown with rapeseed and other crops for the last six years. 'Ostrivets' grassland was formerly used as a hayfield. However, in the early XXI century, the traditional management ceased and was replaced by annual early spring burning of dry grass. Such a disturbance lasted to 2013, and after renewal of cultivation of arable lands, the meadow steppe patch happened to be completely abandoned.

We studied species composition of vascular plants in three permanent sample plots, $5 \times 5 \mathrm{~m}^{2}$ in size in the years 2010 (vegetation was disturbed by fire), 2014 (one year after the cessation) and 2018 (five years after abandonment). Species records were made three times during a vegetation period: in March-April, in early June and in early August.

Projective cover in percent was estimated for each species.

We used the Sørensen-Dice coefficient to calculate the similarity of species composition of the flora in sample plots between the years of study (KS) (Shmidt, 1980).

$$
K_{S}=\frac{2 N_{a+b}}{\left(N_{a}+N_{b}\right)},
$$

where $N_{a+b}$ is the number of common species growing in sample plots in both years ( $a$ and $b$ ); $N_{a}$ and $N_{b}$ - are the general number of species per plot in a certain year.

Nomenclature of plant species follows Mosyakin \& Fedoronchuk (1999). Systematics follow Mosyakin \& Tyshchenko (2010) and Mosyakin (2013).

\section{Results}

General species number at three plots during the whole study period was 145. The highest species richness was found in 2010 (114 species of vascular plants in three plots), it slightly decreased when examined in 2014 (108 species) and was considerably lower in 2018 (83 species) (Table 1). Expressed in percentage terms, species richness per plot is equal to $78.6 \%, 74.5 \%$ and $57.2 \%$, respectively. We have found significant changes in species composition during the study period. As many as 55 species (37.9\%) remained in the grassland from 2010 till 2018, however most of them experienced alterations in projective cover.

Dry vegetation burning had stopped by 2013, thus a year later soil was covered with litter layer of 10-15 cm depth. Brachypodium pinnatum still dominated within the community, as had been marked in 2010, with mean projective cover $60 \%$ in both years. 25 species disappeared from the community in the years 2010-2014. Most of them are low-growing species typical for xerothermic grasslands (meadow steppes) (Adonis vernalis, Astragalus danicus, Carex montana, Centaurea stricta, Chamaecytisus paczoskii, Dianthus carthusianorum, Euphorbia angulata, Helianthemum chamaecystus, Lathyrus pannonicus, Pulsatilla grandis, Thesium linophyllon, Veronica spicata etc.). Instead of this, twenty new species appeared in the patch in 2014. Among them are mostly mesophilous meadow species (Anthoxantum odoratum, Galium mollugo,
Geranium pratense, Holcus lanatus, Leucanthemum vulgaris, Poa pratensis, P. trivialis), complemented with species of forests and forest edges (Anthriscus sylvestris, Chamaerion angustifolium, Convallaria majalis, Lathyrus sylvestris, Melandrium album, Pteridium aquilinum, Rubus caesius, Scrophularia nodosa).

Table 1

Projective cover of species (\%) of Ostrivets habitat

\begin{tabular}{|c|c|c|c|}
\hline \multirow{2}{*}{ Plant species } & \multicolumn{3}{|c|}{ Years of study } \\
\hline & 2010 & 2014 & 2018 \\
\hline Dennstaedtiaceae & & & \\
\hline $\begin{array}{c}\text { Pteridium aquilinum }(\mathrm{L} .) \text { Kuhn } \\
\text { Melanthiaceae }\end{array}$ & - & 1.0 & 2.0 \\
\hline $\begin{array}{c}\text { Veratrum lobelianum Bernh. } \\
\text { Liliaceae }\end{array}$ & 1.0 & 2.0 & 2.0 \\
\hline $\begin{array}{l}\text { Lilium martagon L. } \\
\text { Orchidaceae }\end{array}$ & 0.5 & 0.2 & 0.1 \\
\hline Dactylorhiza maculata (L.) Soó & 0.1 & - & - \\
\hline Gymnadenia conopsea (L.) R. Br. & 0.2 & 0.1 & - \\
\hline $\begin{array}{c}\text { Platanthera bifolia (L.) Rich. } \\
\text { Iridaceae }\end{array}$ & 0.1 & 0.1 & - \\
\hline $\begin{array}{c}\text { Gladiolus imbricatus L. } \\
\text { Alliaceae }\end{array}$ & 2.0 & 5.0 & 1.0 \\
\hline $\begin{array}{r}\text { Allium oleraceum } \mathrm{L} . \\
\text { Agavaceae }\end{array}$ & 0.1 & 0.1 & 0.1 \\
\hline Anthericum ramosum $\mathrm{L}$. & 2.0 & 0.5 & 0.2 \\
\hline $\begin{array}{l}\text { Polygonatum odoratum (Mill.) Druce } \\
\text { Ruscaceae }\end{array}$ & 0.2 & 0.1 & 0.1 \\
\hline $\begin{array}{c}\text { Convallaria majalis } \mathrm{L} . \\
\text { Juncaceae }\end{array}$ & - & 1.5 & 2.0 \\
\hline $\begin{array}{c}\text { Luzula campestris (L.) DC. } \\
\text { Cyperaceae }\end{array}$ & 1.0 & 1.0 & - \\
\hline Carex montana $\mathrm{L}$. & 5.0 & - & - \\
\hline $\begin{array}{l}\text { C. michelii Host } \\
\text { Poaceae }\end{array}$ & 0.1 & 0.1 & - \\
\hline Agrostis capillaris L. & 0.5 & 0.2 & - \\
\hline Anthoxantum odoratum L. & - & 0.2 & - \\
\hline Arrhenatherum elatius (L.) J. Presl \& C. Presl & 5.0 & 2.0 & 10.0 \\
\hline Brachypodium pinnatum (L.) P. Beauv. & 60.0 & 60.0 & 10.0 \\
\hline Briza media L. & 1.0 & 2.0 & 5.0 \\
\hline Bromopsis inermis (Leyss.) Holub & 5.0 & 5.0 & 10.0 \\
\hline Calamagrostis epigeios (L.) Roth & 1.0 & 10.0 & 2.0 \\
\hline Dactylis glomerata $\mathrm{L}$. & 0.2 & 0.2 & 0.5 \\
\hline Elytrigia intermedia (Host) Nevski & 0.5 & 1.0 & - \\
\hline Festuca valesiaca Gaudin & 10.0 & - & - \\
\hline Holcus lanatus L. & - & 0.5 & 0.5 \\
\hline Molinia arundinacea Schrank & 10.0 & 20.0 & 85.0 \\
\hline Poa nemoralis L. & 0.1 & 1.0 & 1.0 \\
\hline P. pratensis $\mathrm{L}$. & - & 0.5 & 0.5 \\
\hline P. trivialis L. & - & 10.0 & - \\
\hline $\begin{array}{c}\text { Trisetum flavescens (L.) P. Beauv. } \\
\text { Ranunculaceae }\end{array}$ & 0.1 & 0.2 & - \\
\hline Adonis vernalis $\mathrm{L}$. & 0.2 & - & - \\
\hline Anemone narcissiflora $\mathrm{L}$. & 0.5 & 0.1 & - \\
\hline A. sylvestris L. & 2.0 & 0.5 & - \\
\hline Pulsatilla grandis Wender & 0.5 & - & - \\
\hline Ranunculus auricomus L. & 0.1 & 0.1 & - \\
\hline R. zapałowiczii Pacz. & 0.5 & - & - \\
\hline $\begin{array}{r}\text { Thalictrum minus } \mathrm{L} . \\
\text { Fabaceae }\end{array}$ & 0.5 & 0.5 & - \\
\hline Astragalus danicus Retz. & 0.5 & - & - \\
\hline A. glycyphyllos L. & - & 0.5 & 1.0 \\
\hline Chamaecytisus blockianus (Pawł.) Klásková & 5.0 & 2.0 & - \\
\hline Ch. paczoskii (V. Krecz.) Klásková & 0.2 & - & - \\
\hline Genista tinctoria $\mathrm{L}$. & 5.0 & 2.0 & - \\
\hline Lathyrus niger (L.) Bernh. & 0.5 & 0.5 & 0.5 \\
\hline L. pannonicus (Jacq.) Garcke & 0.1 & - & - \\
\hline L. sylvestris L. & - & 0.5 & - \\
\hline Lotus corniculatus L. s.l. & 2.0 & 2.0 & 0.5 \\
\hline Medicago falcate L. s.l. & 5.0 & 5.0 & 2.0 \\
\hline Securigera varia (L.) Lassen & 12.0 & 15.0 & 5.0 \\
\hline Trifolium alpestre L. & 2.0 & 2.0 & 1.5 \\
\hline T. montanum L. & 0.5 & 0.5 & 0.2 \\
\hline T. pannonicum Jacq. & 1.0 & 2.0 & 2.0 \\
\hline Vicia sepium $\mathrm{L}$. & - & - & 0.1 \\
\hline V. tenuifolia Roth & 5.0 & 2.0 & 1.0 \\
\hline
\end{tabular}




\begin{tabular}{|c|c|c|c|c|c|c|c|}
\hline \multirow{2}{*}{ Plant species } & \multicolumn{3}{|c|}{ Years of study } & \multirow{2}{*}{ Plant species } & \multicolumn{3}{|c|}{ Years of study } \\
\hline & 2010 & 2014 & 2018 & & 2010 & 2014 & 2018 \\
\hline Polygalaceae & & & & Orobanchaceae & & & \\
\hline $\begin{array}{c}\text { Polygala comosa Schkuhr } \\
\text { Rosaceae }\end{array}$ & 0.1 & - & - & $\begin{array}{l}\text { Rhinanthus aestivalis (N. Zinger) Schischk. } \\
\text { \& Serg. }\end{array}$ & 0.2 & 0.2 & - \\
\hline Filipendula vulgaris Moench & 1.5 & 0.2 & - & Campanulaceae & & & \\
\hline Maluss ylvestris Mill. & - & - & 1.0 & Adenophora lilifolia (L.) Ledeb. ex A. DC. & 0.2 & 0.1 & 0.2 \\
\hline Potentilla alba $\mathrm{L}$. & 20.0 & 5.0 & 2.0 & Campanula cervicaria $\mathrm{L}$. & 0.5 & 0.5 & 1.0 \\
\hline P. erecta (L.) Raeusch. & 2.0 & 2.0 & 1.0 & C. glomerata $\mathrm{L}$. & - & - & 0.2 \\
\hline Prunus spinosa $\mathrm{L}$. & - & - & 5.0 & C. persicifolia $\mathrm{L}$. & 0.1 & 0.1 & - \\
\hline Rubus caesius L. & - & 5.0 & 20.0 & C. trachelium $\mathrm{L}$. & 0.1 & 0.1 & 0.5 \\
\hline R. idaeus L. & - & 1.0 & 2.0 & Asteraceae & & & \\
\hline Sanguisorba officinalis L. & 0.5 & 1.0 & 5.0 & Achillea millefoliumL. s.l. & - & - & 0.2 \\
\hline Fagaceae & & & & Artemisia vulgaris L. & - & 0.2 & 0.5 \\
\hline Quercus robur L. & 0.5 & 2.0 & 5.0 & Carlina cirsioides Klokov & 5.0 & 1.0 & - \\
\hline Betulaceae & & & & Centaurea pannonica (Heuff.) Simonk. & 0.5 & 1.0 & 1.0 \\
\hline Betula pendula Roth & - & - & 5.0 & C. scabiosa L. s.l. & 2.0 & 5.0 & 2.0 \\
\hline Carpinus betulus L. & - & 1.0 & 5.0 & C. stricta Waldst. \&Kit. & 0.1 & - & - \\
\hline Corylus avellana L. & - & - & 2.0 & Cirsium erisithales (Jacq.) Scop. & 1.0 & 1.0 & 0.5 \\
\hline Salicaceae & & & & C. pannonicum (L. f.) Link & 0.1 & - & - \\
\hline Populus tremula $\mathrm{L}$. & 0.1 & 2.0 & 10.0 & Hieracium umbellatum L. & 0.5 & 1.0 & 2.0 \\
\hline Salix caprea $\mathrm{L}$. & - & - & 5.0 & Hypochaeris maculate L. & 5.0 & 5.0 & 2.0 \\
\hline Violaceae & & & & Inula hirta $\mathrm{L}$ & 2.0 & 0.5 & - \\
\hline Viola hirta L. & 0.1 & - & - & Leontodon hispidus L. & 0.1 & - & - \\
\hline V. montana L. s. str. & 0.1 & 0.1 & - & Leucanthemum vulgare Lam. & & 0.2 & - \\
\hline Euphorbiaceae & & & & Serratula lycopifolia (Vill.) A. Kern. & 2.0 & - & - \\
\hline Euphorbia angulata Jacq. & 0.1 & - & - & S. tinctoria $\mathrm{L}$. & 0.5 & 2.0 & 5.0 \\
\hline Geraniaceae & & & & Solidago virgaurea $\mathrm{L}$. & 2.0 & 5.0 & 5.0 \\
\hline Geranium pratense L. & - & 0.2 & 0.5 & Pyrethrum corymbosum (L.) Scop. & 1.0 & 2.0 & 2.0 \\
\hline G. sanguineum L. & 2.0 & 1.0 & 0.2 & Tanacetum vulgare $\mathrm{L}$. & 0.2 & 5.0 & 20.0 \\
\hline Onagraceae & & & & Tragopogon major Jacq. & 0.2 & 0.2 & - \\
\hline Chamaerion angustifolium (L.) Holub & - & 0.2 & 1.0 & Viburnaceae & & & \\
\hline Tiliaceae & & & & Viburnum opulus L. & - & - & 1.0 \\
\hline Tilia cordata Mill. & - & 1.0 & 2.0 & Caprifoliaceae & & & \\
\hline Cistaceae & & & & Knautia arvensis (L.) Coult. & 0.1 & 0.2 & 0.2 \\
\hline Helianthemum chamaecystus Mill. & 0.1 & - & - & Scabiosa ochroleuca L. & 0.1 & 0.1 & - \\
\hline Santalaceae & & & & Succisa pratensis Moench & 0.5 & 0.2 & - \\
\hline Thesium linophyllon $\mathrm{L}$. & 2.0 & - & - & Apiaceae & & & \\
\hline Caryophyllaceae & & & & Anthriscus sylvestris L. & - & 0.5 & 0.5 \\
\hline Dianthus carthusianorum L. & 0.1 & - & - & Bupleurum falcatum $\mathrm{L}$. & 0.2 & 0.1 & - \\
\hline Melandrium album (Mill.) Garcke & - & 0.1 & - & Ferulago sylvatica (Besser) Rchb. & 2.0 & 5.0 & 1.0 \\
\hline Oberna behen (L.) Ikonn. & 0.1 & 0.1 & 0.1 & Heracleum sibiricum $\mathrm{L}$. & 0.2 & 0.5 & 1.0 \\
\hline Silene nutans L. & 0.1 & - & - & Laserpitium latifolium $\mathrm{L}$. & 2.0 & 5.0 & 10.0 \\
\hline Stellaria graminea L. & 0.2 & 0.5 & 0.5 & Peucedanum cervaria (L.) Lapeyr. & 10.0 & 10.0 & 5.0 \\
\hline Primulaceae & & & & P. oreoselinum (L.) Moench & 5.0 & 5.0 & 2.0 \\
\hline Lysimachia vulgaris $\mathrm{L}$. & 0.5 & 0.5 & 0.2 & Seseli libanotis (L.) W. D. J. Koch & & & \\
\hline Primula veris L. & 5.0 & 2.0 & - & subsp. intermedium (Rupr.) P. W. Ball & 5.0 & 5.0 & 1.0 \\
\hline
\end{tabular}

Asperula cynanchica L.

Cruciata glabra (L.) Ehrend.

Galium album Mill.

G. boreale L.

G. mollugo L.

G. verum L. Apocynaceae

Vincetoxicum hirundinaria Medik. s.l. Boraginaceae

Myosotis arvensis (L.) Hill

Convolvulaceae

Calystegia sepium (L.) R. Br.

Convolvulus arvensis L.

Plantaginaceae

Digitalis grandiflora Mill.

Linaria vulgaris Mill.

Plantago media L.

Veronica austriaca $\mathrm{L}$.

V. montana L.

V. spicata $\mathrm{L}$.

\section{Scrophulariaceae}

Scrophularia nodosa L. Lamiaceae

Betonica officinalis L.

Melittis sarmatica Klokov

Salvia pratensis L.

$S$. verticillata $\mathrm{L}$.

Stachys recta $\mathrm{L}$.

Teucrium chamaedrys L.

Thymus pulegioides L. s.l.

In 2018 the projective cover of Brachypodium pinnatum decreased to $10 \%$, so the dominant species has changed. Molinia arundinacea has formed a dense stand of $2 \mathrm{~m}$ height with projective cover $85 \%$. Depth of litter cover above soil reached $30 \mathrm{~cm}$. The habitat lost 36 more species in the period of 2014-2018; many of them are typical for meadow-steppe vegetation (Anemone sylvestris, Asperula cynanchica, Bupleurum falcatum, Carex mickeli, Chamaecytisus blockianus, Elytrigia intermedia, Filipendula vulgaris, Genista tinctoria, Inula hirta, Teucrium chamaedrys, Thalictrum minus etc.). Nine new species were found there instead.

We represented shifts of species composition of flora during the study period in a form of pairwise Sørensen-Dice's similarity coefficient (Table 2).

Table 2

Similarity matrix of species composition at studied plots for the period of observation

\begin{tabular}{cccc}
\hline Years & 2010 & 2014 & 2018 \\
\hline 2010 & - & 85 & 55 \\
2014 & 0.77 & - & 80 \\
2018 & 0.56 & 0.84 & - \\
\hline
\end{tabular}

Note: values above the diagonal are number of species common to both years; values below the diagonal are pairwise Sørensen-Dice's similarity coefficient.

Dissimilarity of floristic composition between the years of first and second, as well as of second and third recording was slightly fewer than half of the general species number (41.4-44.2\%). Species composition shift for the whole study period (2010-2018 years) was significant 
(61.4\%). 'Ostrivets' grassland has been rapidly overgrown with trees and shrubs during the study period. In 2010 only two young trees grew within the patch (Populus tremula and Quercus robur), forming general projective cover of $0.6 \%$. In 2014 there appeared two new species - Tilia cordata and Carpinus betulus, and their total projective cover increased to $6 \%$. Additionally, Rubus caesius appeared within the community and got to the overgrown stage (projective cover - 5\%). In 2018 six new species of shrubs and trees entered the vegetation: Betula pendula, Corylus avellana, Malus sylvatica, Prunus spinosa, Salix caprea, Viburnum opulus. Their general projective cover continued to increase (15-20\%) as well as the cover of Rubus caesius (up to $20 \%$ ).

The relation between eco-coenotical groups of species has been also considerably changing during the study period (Fig. 1).
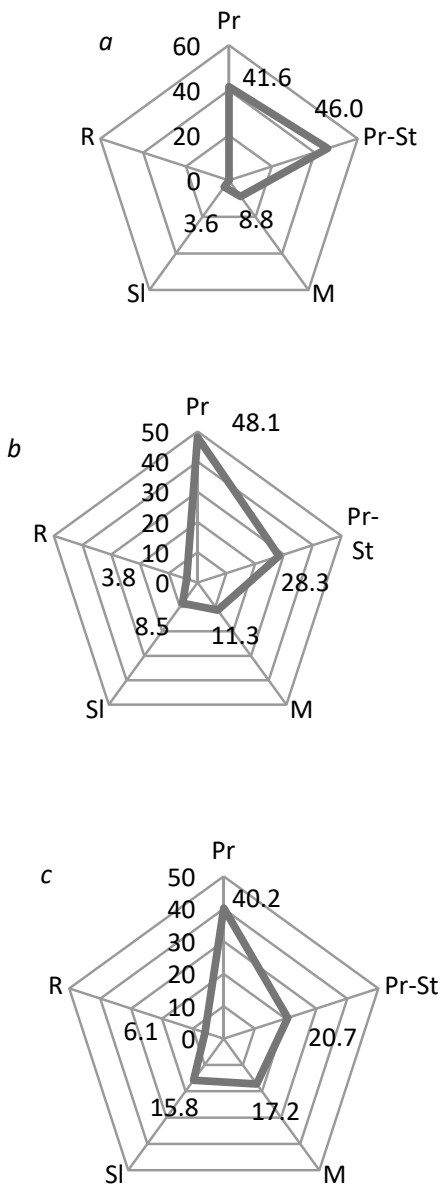

Fig. 1. Eco-coenotical structure of flora of studied plots in 'Ostrivets' grassland: years of study: $a-2010, b-2014, c-2018$; abbreviations of eco-coenotical groups of plants: $\mathrm{Pr}$ - meadow species; $\mathrm{Pr}-\mathrm{St}$ - meadow-steppe species; $\mathrm{M}$ - forest edge species; $\mathrm{Sl}$ - forest species; $\mathrm{R}$-ruderal species

In 2010 the two dominant eco-coenotical groups were meadowsteppe and meadow species groups. The number of forest and forest edge species were much lower. The proportion of meadow-steppe species in the next two periods of observation halved, whereas meadow species began to dominate in the community. The number of forest edge species doubled, of forest species - increased fourfold, also ruderal species appeared.

'Ostrivets' xerothermic grassland was a habitat for many rare species. In 2010 eleven species were found listed in the Red Data Book of Ukraine, one species in Annex I of Bern Convention - Pulsatilla grandis; one species in Revised Annex I of Resolution 6 of the Bern ConventionAdenophora lilifolia and three species in Annex IV of Council Directive 92/43/EEC - Pulsatilla grandis, Adenophora lilifolia and Serratula lycopifolia. A range of regionally rare species were also noticed in the habitat.

However, the majority of these species disappeared with succession development. In 2014 we failed to find Adonis vernalis, Chamaecytisus paczoskii, Dactylorhiza maculata, Pulsatilla grandis, Serratula lycopifolia, in 2018 there was no sign of Anemone narcissifolia, Carlina cirsioides, Chamaecytisus blockianus, Gymnadenia conopsea and Platanthera bifolia. Only three rare species, which is equal to $23.1 \%$, remained in the grassland in 2018 (Adenophora lilifolia, Gladiolus imbricatus and Lilium martagon), but with decreased projective cover.

\section{Discussion}

Changes in species composition of 'Ostrivets' xerothermic grassland are generated by two consistent events: annual burning and abandonment. Cessation of any disturbance initiated succession processes while frequent fire had defined their direction. Usually xerothermic grasslands after abandonment experience increasing dominance of Brachypodium pinnatum (Bobbink \& Willems, 1987, 1991; Kahmen et al., 2002; Kohler et al., 2005), sometimes of Arrhenatherum elatius (Dostálek \& Frantík, 2008) and other competitively strong species (Garadnai, 2007; Hille \& Goldammer, 2007; Marozas et al., 2007; Hegedušová \& Senko, 2011; Deák et al., 2014). Brachypodium pinnatum can gain over $80 \%$ of vegetation cover and induce a decrease in species number to less than $50 \%$ of the original number (Bobbink \& Willems, 1987). Increased abundance of this species may occur after abandonment of traditional management, as well as under different management practices (Zimmermann 1979; Wilmanns \& Kratochwil, 1983; Bobbink \& Willems, 1987). Therefore, much research is focused on developing methods to control density of Brachypodium pinnatum in grasslands (Bobbink et al., 1988; Bobbink \& Willems, 1991; Schlaepfer 1997; Farmer \& Baxter, 1998; Hurst, 1999; Redhead et al., 2019).

Among meadow steppes of Podillia Brachypodium pinnatum grasslands are one of the most species-rich habitats (Roleček et al., 2019). In other regions Brachypodium pinnatum dominated grasslands also harbour high species richness (Illyés et al., 2009; Roleček et al., 2014). In dry grasslands of Opillia the tor-grass usually has projective cover 50 $70 \%$ forming pure stands only on tops of hills with lack of disturbance. In our study the primary cover of the dominant species was $60 \%$ and it remained unchanged after at least five years of annual burning. However, during the next five years of abandonment Brachypodium pinnatum was replaced by Molinia arundinacea.

Purple moor-grass is supposed to invade different habitat types after frequent fires (Bensettiti et al., 2005; Jacquemyn et al., 2005; Calaciura \& Spinelli, 2008). Also some papers reported increased dominance of other tall competitive grasses such as Brachypodium pinnatum (Kahmen et al., 2002; Köhler et al., 2005), Calamagrostis epigeios (Hille \& Goldammer, 2007; Marozas et al., 2007) or Phragmites australis (Deák et al., 2014).

In our study abundance of Brachypodium pinnatum between the years 2010 and 2014 remained unchanged, but there was a significant decrease in it after five years of abandonment. Abundance of Molinia arundinacea doubled in 2014 against 2010 (10\% and 20\%, respectively) and increased up to $85 \%$ in 2018 after abandonment. Burning and abandonment did not significantly foster or delay the expansion of other competitors (projective cover of Arrhenatherum elatius decreased from $5 \%$ in 2010 to $2 \%$ in 2014 , but then increased to $10 \%$ in 2018 , whereas the cover of Calamagrostis epigeios increased from $1 \%$ to $10 \%$ after annual burning, however it almost reached the initial level after cessation of disturbance). Frequent burning allowed the encroachment of such species as Rubus caesius, R. idaeus and Pteridium aquilinum. Projective cover of the first species reached $20 \%$ in 2018 and counting.

Fire as the method of supporting species richness in European grasslands is highly controversial. On the one hand, burning is the easiest way to eliminate accumulated plant litter in abandoned grasslands, to suppress shrubs and pioneer trees encroachment and, thus, to sustain appropriate habitat conditions for existence of xerothermic species, including a great variety of rare species. Many plant species respond well to quick fire, exhibit no damage after burning of their above-ground parts or even benefit from fire (Deák et al., 2014; Feurdean, 2018). Recent research has 
shown that fire had been much more important to developing and maintaining of grassland vegetation in Europe than had been thought before (Valkó et al., 2016; Pereira et al., 2017; Feurdean, 2018).

However, a lot of research has shown negative impacts of fire on vegetation in European grasslands due to increased germination of invasive species, dominance of Brachypodium pinnatum and decreased species richness (Kahmen et al., 2002; Moog et al., 2002; Kohler et al., 2005; Pereira et al., 2017).

'Ostrivets' grassland had been under fire regime for no less than five years running. We examined floristic composition after a year of cessation of annual burning and compared it to the species composition in 2010 (during annual burning). While the general species number did not significantly decrease (6 species), species composition considerably changed. Species characteristic for meadow steppes (e.g. Adonis vernalis, Pulsatilla grandis, Thesium linophyllon, Lathyrus pannonicus etc.) were substituted for species common for meadows, forests and shrub edges. Ruderal species also were noticed in the habitat. Our results show that at the beginning of disturbance by annual fire, burning was not detrimental for plant cover of 'Ostrivets' grassland, while five or more years of annual burning were too much and caused a degradation of the habitat.

The next five years of abandonment, instead of regeneration, brought further deterioration of habitat quality. Molinia arundinacea became dominant, created a thick litter layer, the habitat was gradually overtaken by woody species, European dewberry and others. Altogether 61 species disappeared from the habitat. Abundance of forest species, species of forest edges and ruderals considerably increased.

'Ostrivets' grassland harboured populations of thirteen rare species. In 2010 eleven species were found listed in the Red Data Book of Ukraine (Diukh, 2009) (Adonis vernalis, Anemone narcissiflora, Carlina cirsioides, Chamaecytisus blockianus, Ch. paczoskii, Dactylorhiza maculata, Gladiolus imbricatus, Gymnadenia conopsea, Lilium martagon, Platanthera bifolia, Pulsatilla grandis) and three species in international conservation lists (1 - in Annex I of Bern Convention (1979) - Pulsatilla grandis; 1 - in Revised Annex I of Resolution 6 of the Bern Convention (2011) - Adenophora lilifolia; 3 - in Annex IV of Council Directive 92/43/EEC (1992) - Pulsatilla grandis, Adenophora lilifolia, Serratula lycopifolia). In 2014 we found no sign of Adonis vernalis, Chamaecytisus paczoskii, Dactylorhiza maculata, Pulsatilla grandis and Serratula lycopifolia. In 2018 only three rare species grew within the habitat (Adenophora liliifolia, Gladiolus imbricatus and Lilium martagon).

'Ostrivets' grassland is a valuable patch of xerothermic grasslands, which are highly endangered throughout the Europe (Calaciura \& Spinelli, 2008). It harboured both high species richness and a range of rare species. However, the habitat currently needs management measures to suppress its overgrowth and degradation. The first step is removing woody vegetation. Taking into consideration the disposition of the patch (far from adjacent villages and surrounded by agricultural lands), the most appropriate management practice would be mowing. It might be combined with burning, however at most once in three-five years (Deák et al., 2014). After these measures are taken, restoration of origin species composition will require overseeding of the lost species because of the impermanent character of the seed bank of calcareous grasslands (Butaye et al., 2005).

\section{Conclusion}

The traditionally mowed grassland 'Ostrivets' became a refugium for xerothermic flora with high species richness. The species composition was complemented by meadow species, and in a minor way - by species of forests and forest edges. After the cessation of traditional management, the original habitat conditions had been maintained by early spring annual burning for a few years without any significant deterioration of the habitat quality. However, continuation of burning resulted in decrease of general species richness, encroachment of shrubs, trees and ruderals, increase of proportions of species of forests and forest edges, loss of populations of rare species. The next five years of abandonment completely transformed the habitat. The dominant species (Brachypodium pinnatum) was substituted by Molinia arundinacea. The projective cover of woody vegetation reached $20 \%$ and the same area was under Rubus caesius. Only three (Adenophora liliifolia, Gladiolus imbricatus and Lilium martagon) of thirteen rare species remained in sample plots after abandonment. Without some urgent measures, such as tree and shrub removal and implementation of traditional management 'Ostrivets' grassland will soon be completely overgrown.

\section{References}

Bensettiti, F., Boullet, V., Chavaudret-Laborie, C., \& Deniaud, J. (Eds.). (2005). Cahiers d'habitats Natura 2000. Connaissance et gestion des habitats et des espèces d'intérêt communautaire. Tome 4 - Habitats agropastoraux ["Habitats Manuals" Natura 2000. Knowledge and management of habitats and species of Community interest. Tome 4-Agropastoral habitats]. The French Documentation, Paris (in French).

Bobbink, R., \& Willems, J. H. (1987). Increasing dominance of Brachypodium pinnatum (L.) Beauv. in chalk grasslands: A threat to a species-rich ecosystem. Biological Conservation, 40(4), 301-314.

Bobbink, R., \& Willems, J. H. (1991). Impact of different cutting regimes on the performance of Brachypodium pinnatum in Dutch chalk grassland. Biological Conservation, 56, 1-21.

Bobbink, R., Bikand, L., \& Willems, J. H. (1988). Effects of nitrogen fertilization on vegetation structure and dominance of Brachypodium pinnatum (L.) Beauv. in chalk grassland. Acta Botanica Neerlandica, 37(2), 231-242.

Butaye, J., Adriaens, D., \& Honnay, O. (2005). Conservation and restoration of calcareous grasslands: A concise review of the effects of fragmentation and management on plant species. Biotechnology, Agronomy and Society and Environment, 9(2), 111-118.

Calaciura, B., \& Spinelli, O. (2008). Management of Natura 2000 habitats. 6210. Semi-natural dry grasslands and scrubland facies on calcareous substrates (Festuco-Brometalia) (*important orchid sites). European Commission, Brussels.

Deák, B., Valkó, O., Török, P., Végvári, Z., Hartel, T., Schmotzer, A., Kapocsi, I., \& Tóthmérész, B. (2014). Grassland fires in Hungary - Experiences of nature conservationists on the effects of fire on biodiversity. Applied Ecology and Environmental Research, 12(1), 267-283.

Didukh, Y. P. (Ed.). (2009). Chervona knyha Ukrayiny. Roslynnyi svit [The Red Data Book of Ukraine. Plant world]. Hlobalkonsaltynh, Kyiv (in Ukrainian).

Dmytrash-Vatseba, I. I. (2016). Stan zberezhennia populiatsii rarytetnykh vydiv roslyn v umovakh antropohennoi transformatsii luchnykh stepiv Pivdennoho Opillia [Conservation state of populations of rare plant species in highly transformed meadow steppes of Southern Opillya]. Visnyk of Dnipropetrovsk University, Biology, Ecology, 24(2), 353-358 (in Ukrainian).

Dmytrash-Vatseba, I. I. (2017). Modeliuvannia zmin rarytetnoho fitoriznomanittia luchnykh stepiv Pivdennoho Opillia pid vplyvom antropohennykh chynnykiv [Modeling of rare plant species diversity changes by anthropogenic factors in meadow steppes of the Southern Opillya]. Proceedings of the State Natural History Museum, 33, 133-142 (in Ukrainian).

Dostálek, J., \& Frantík, T. (2008). Dry grassland plant diversity conservation using low-intensity sheep and goat grazing management: Case study in Prague (Czech Republic). Biodiversity and Conservation, 17(6), 1439-1454.

Dzwonko, Z., \& Loster, S. (1998). Dynamics of species richness and composition in a limestone restored after cutting. Journal of Vegetation Science, 9(3), 387-394.

Farmer, A. M., \& Baxter, D. (1998). A review of management options for the control of Brachypodium pinnatum in calcareous grassland in England. Journal of Practical Ecology and Conservation, 2, 9-18.

Feurdean, A., Ruprecht, E., Molnár, Z., Hutchinson, S. M., \& Hickler, T. (2018). Biodiversity-rich European grasslands: Ancient, forgotten ecosystems. Biological Conservation, 228, 224-232

Garadnai, J. (2007). Az égetés hatásai az árvalányhajas gyepekre - esettanulmány [Effects of burning in Stipa dominated steppes - a case study]. In: Illyés, E., Bölöni, J. (szerk.). Lejtősztyepek, löszgyepek és erdőssztyeprétek Magyarországon [Slope steppes, loess steppes and forest steppe meadows in Hungary]. Private Press, Budapest, 112-113 (in Hungarian).

Gorban, V., Huslystyi, A., Kotovych, O., \& Yakovenko, V. (2020). Changes in physical and chemical properties of calcic chernozem affected by Robinia pseudoacacia and Quercus robur plantings. Ekolgia (Bratislava), 39(1), 27-44.

Hansson, M., \& Fogelfors, H. (2000). Management of a semi-natural grassland; results from a 15-year-old experiment in southern Sweden. Joumal of Vegetation Science, 11, 31-38.

Hegedušová, K., \& Senko, D. (2011). Successional changes of dry grasslands in Southwestern Slovakia after 46 years of abandonment. Plant Biosystems, 145(3), 666-687.

Hille, G. M., \& Goldammer, G. J. (2007). Dispatching and modeling of fires in Central European pine stands: New research and development approaches in Germany. 4th International Wildland Fire Conference (13-17 May 2007, Seville). P. 49 .

Hurst, J. E. (1999). The effectiveness of glyphosate for controlling Brachypodium pinnatum in chalk grassland. Biological Conservation, 89, 261-265. 
Illyés, E., Bauer, N., \& Botta-Dukát, Z. (2009). Classification of semi-dry grassland vegetation in Hungary. Preslia, 81, 239-260.

Jacquemyn, H., Brys, R., \& Neubert, M. G. (2005). Fire increase invasive spread of Molinia caerulea mainly through changes in demographic parameters. Ecological Applications, 15(6), 2097-2108.

Kahmen, S., Poschlod, P., \& Schreiber, K.-F. (2002). Conservation management of calcareous grasslands. Changes in plant species composition and response of functional traits during 25 years. Biological Conservation, 104, 319-324.

Köhler, B., Gigon, A., Edwards, P. J., Krüsi, B., Langenauer, R., Lüscher, A., \& Ryser, P. (2005). Changes in the species composition and conservation value of limestone grasslands in Northern Switzerland after 22 years of contrasting managements. Perspectives in Plant Ecology, Evolution and Systematics, 7, 51-67.

Krauss, J., Klein, A., Steffan-Dewenter, I., \& Tscharntke, T. (2004). Effects of habitat area, isolation, and landscape diversity on plant species richness of calcareous grasslands. Biodiversity and Conservation, 13, 1427-1439.

Kukovytsia, H. S., Didukh, Y. P., Sheliag-Sosonko, Y. R., \& Abduloeva, O. S. (1998). Syntaksonomiia luchnykh stepiv pamiatok pryrody respublikanskoho znachennia hh. Kasova ta Chortova [Syntaxonomy of meadow steppes of natural monuments of republic importance Mts. Kasova and Chortova]. Ukrainian Phytocenological Proceedings, 11(2), 42-61 (in Ukrainian).

Kukovytsia, H. S., Movchan, Y. I., Solomakha, V. A., \& Sheliag-Sosonko, Y. R. (1994). Syntaksonomiia luchnykh stepiv Zakhidnoho Podillia [Syntaxonomy of meadow steppes of the Western Podolia]. Ukrainian Botanical Journal, 51(2-3), 35-48 (in Ukrainian).

Marozas, V., Racinskas, J., \& Bartkevicius, E. (2007). Dynamics of ground vegetation after surface fires in hemiboreal Pinus sylvestris L. forests. 4th International Wildland Fire Conference (13-17 May 2007), Seville. P. 22.

Moog, D., Poshlod, P., Kahmen, S., \& Schreiber, K. F. (2002). Comparison of species composition between different grassland management treatments after 25 years. Applied Vegetation Science, 5, 96-106.

Mosyakin, S. L. (2013). Rodyny i poriadky kvitkovykh roslyn flory Ukrainy: Prahmatychna klasyfikatsiia ta polozhennia u filohenetychnii systemi [Families and orders of Angiosperms of the flora of Ukraine: A pragmatic classification and placement in the phylogenetic system]. Ukrainian Botanical Journal, 70(3), 289-307 (in Ukrainian).

Mosyakin, S. L., \& Fedoronchuk M. M. (1999). Vascular plants of Ukraine. A nomenclatural checklist. M. G. Kholodny Institute of Botany, Kyiv.

Mosyakin, S. L., \& Tyshchenko, O. V. (2010). Prahmatychna filohenetychna klasyfikatsiia sporovykh sudynnykh roslyn flory Ukrainy [A pragmatic phylogenetic classification of vascular cryptogamic plants of the flora of Ukraine]. Ukrainian Botanical Journal, 67(6), 802-817 (in Ukrainian).

Pereira, P., Francos, M., Ubeda, X., \& Brevik, E. C. (2017). Fire impacts in European grassland ecosystems. In: Bento-Gonçalves A. J. (Ed.) Wildfires. Perspectives, issues and challenges of the 21st century. Nova Science Publishers, Inc. Pp. 1-27.

Poschlod, P., \& Wallis De Vries, M. F. (2002). The historical and socioeconomic perspective of calcareous grasslands: Lessons from the distant and recent past. Biological Conservation, 104, 361-376.

Poschlod, P., Bakker, J. P., \& Kahmen, S. (2005). Changing land use and its impact on biodiversity. Basic and Applied Ecology, 6, 93-98.

Provoost, S., Ampe, C., Bonte, D., Cosyns, E., \& Hoffmann, M. (2004). Ecology, management and monitoring of dune grassland in Flanders, Belgium. Journal of Coastal Conservation, 22, 33-42.

Pykälä, J., Luoto, M., Heikkinen, R. K., \& Kontula, T. (2005). Plant species richness and persistence of rare plants in abandoned semi-natural grasslands in Northern Europe. Basic and Applied Ecology, 6, 25-33.
Redhead, J. W., Nowakowski, M., Ridding, L. E., Wagner, M., \& Pywell, R. F. (2019). The effectiveness of herbicides for management of tor-grass (Brachypodium pinnatum s.1.) in calcareous grassland. Biological Conservation, 237, 280-290.

Roleček, J., Čornej, I. I., \& Tokarjuk, A. I. (2014). Understanding the extreme species richness of semi-dry grasslands in east-central Europe: A comparative approach. Preslia, 86, 13-34.

Roleček, J., Hájek, M., Dřevojan, P., Prokešová, H., Fajmon, K., Těšitel, J., Daněk, P., Hájková, P., Jongepierová, I., Novák, P., Poluyanov, A. V., Shumska, N. V., \& Chorney, I. I. (2019). Gradients, species richness and biogeographical links of steppe grasslands in Western Podolia (Ukraine). Phytocoenologia, 49(4), 349-367.

Römermann, C., Bernhardt-Römermann, M., Kleyer, M., \& Poschlod, P. (2009) Substitutes for grazing in semi-natural grasslands - Do mowing or mulching represent valuable alternatives to maintain vegetation structure? Journal of Vegetation Science, 20, 1086-1098.

Rudenko, L. H. (Ed.). (2008). National atlas of Ukraine. Instytut Geografiyi NANU, Kyiv (in Ukrainian).

Schlaepfer, F. (1997). Influence of management on cover and seed production of Brachypodium pinnatum (L.) Beauv. in a calcareous grassland. Bulletin of the Geobotanical Institute ETH, 63, 3-10.

Sheliag-Sosonko, Y. R., Didukh, Y. P., \& Yeremenko, L. P. (1981). Roslynnist Kasovoi Hory (Opillia) [Vegetation of Kasova Mountain (Opillia)]. Ukrainian Botanical Journal, 38(3), 60-66 (in Ukrainian)

Shmidt, V. M. (1984). Matematicheskie metodyi v botanike [Mathematical methods in botany]. Leningrad University, Leningrad (in Russian).

Stoate, C., Baldi, A., Beja, P., Boatman, N. D., Herzon, I., van Doom, A., de Snoo, G. R., Rakosy, L., \& Ramwell, C. E. (2009). Ecological impacts of early 21 st century agricultural change in Europe - A review. Journal of Environmental Management, 91, 22-46.

Valkó, O., Deák, B., Magura, T., Török, P., Kelemen, A., Tóth, K., Horváth, R., Nagy, D. D., Debnár, Z., Zsigrai, G., Kapocsi, I., \& Tóthmérész, B. (2016). Supporting biodiversity by prescribed burning in grasslands - A multi-taxa approach. Science of the Total Environment, 572, 1377-1384.

WallisDeVries, M. F., Poschlod, P., \& Willems, J. H. (2002). Challenges for the conservation of calcareous grasslands in Northwestern Europe: Integrating the requirements of flora and fauna. Biological Conservation, 104, 265-273.

When, S., Taugourdeau, S., Johansen, L., \& Hovstad, K. A. (2017). Effects of abandonment on plant diversity in semi-natural grasslands along soil and climate gradients. Journal of Vegetation Science, 28(4), 838-847.

Wilmanns, O., \& Kratochwil, A. (1983). Naturschutz-bezogene Grundlagen-Untersuchungen im Kaiserstuhl [Baseline research for nature conservation in the Kaiserstuhl, West-Germany]. Beih Veröffentlichungen für Naturschutz und Landschaftspflege in Baden-Württemberg, 34, 39-56 (in German).

Zamoroka, A. M., Shumska, N. V., Buchko, V. V., Dmytrash-Vatseba, I. I., Malaniuk, V. B., \& Smirnov, N. A. (2018). The steppe biota of Burshtyn Opillya. Symphonia Forte, Ivano-Frankivsk.

Zimmermann, R. (1979). Der Einfluß des kontrollierten Brennens auf EsparsettenHalbtrockenrasen und Folgegesellschaften im Kaiserstuhl [Controlled burning in the semi-dry grassland of the Kaiserstuhl]. Phylocoenologia, 5, 447-524 (in German).

Zulka, K., Abensperg-Traun, M., Milasowszky, N., Bieringer, G., Gereben-Krenn, B.-A., Holzinger, W., Hölzler, G., Rabitsch, W., Reischütz, A., Querner, P., Sauberer, N., Schmitzberger, I., Willner, W., Wrbka, T., \& Zechmeister, H. (2014). Species richness in dry grassland patches of eastern Austria: A multitaxon study on the role of local, landscape and habitat quality variables. Agriculture, Ecosystems and Environment, 182, 25-36. 